\title{
STUDI OPTIMALISASI KOMPOSISI GLISEROL DAN KITOSAN TERHADAP KARAKTERISTIK SIFAT FISIK PLASTIK BIODEGRADABLE DARI LIMBAH NASI AKING DAN TEPUNG TAPIOKA
}

\author{
Nisa Nurhidayanti*, Indah Yulian Kusuma Wardani, Nur Ilman Ilyas \\ Program Studi Teknik Lingkungan, Fakultas Teknik, Universitas Pelita Bangsa \\ *Email: nisa.kimia@pelitabangsa.ac.id
}

\section{ABSTRACT \\ OPTIMIZATION OF GLYCEROL AND CHITOSAN COMPOSITION CHARACTERISTICS OF THE PHYSICAL PROPERTIES OF BIODEGRADABLE PLASTIC FROM ACE WASTE AND TAPIOCA FLOUR}

\begin{abstract}
Aking rice is rice waste that is no longer suitable for public consumption, however, the high starch content of aking rice can be used as a raw material for making biodegradable plastics. Good biodegradable plastic made from cassava starch and rice flour, to increase its elasticity and extensibility it is necessary to add chitosan additives and glycerol plasticizers. This study aims to determine the optimum conditions for the composition of glycerol and chitosan for the physical properties of biodegradable plastics made from aking rice and tapioca starch. Biodegradable plastics in this study were made with 3 grams of aking rice flour and 7 grams of tapioka flour with the addition of variations in the composition of chitosan ( 3 grams, 5 grams, and 7 grams) and the addition of variations in the composition of glycerol $(2 \mathrm{ml}, 4 \mathrm{ml}, 6 \mathrm{ml}$, and 8 $\mathrm{ml}$ ). As a result, the highest tensile strength value at 7: 2 composition variation is 41.29 $\mathrm{MPa}$, the highest elongation percentage at 3: 8 composition variation is $135.8 \%$, the highest water resistance at 7:8 composition variation is $-206 \%$, the highest percent water absorption and the fastest biodegradation process at a variation of the composition of $3: 2$, namely $1603 \%$ and completely degraded on the 4 th day.
\end{abstract}

Keywords: aking rice, biodegradable plastic, chitosan, glycerol and tapioca starch.

\section{PENDAHULUAN}

Rata-rata masyarakat Indonesia menghasilkan sampah sebanyak 500 gram dan $13 \%$ dari sampah yang dihasilkan berupa sampah plastik yang tidak dapat terurai di lingkungan. Sampah plastik menempati peringkat ketiga dari sampah yang lain yaitu sebesar $9 \%$ atau sebanyak 3,6 juta ton/tahun dari jumlah timbulan sampah yang dihasilkan di Indonesia. Sebanyak $57 \%$ sampah plasti ditemukan di pantai Indonesia, sehinnga Indonesia menempati peringkat kedua negara penghasil sampah kedua setelah China. Pada setiap mil persegi samudera terdapat 46.000 sampah plastik yang mengapung, bahkan sampah plastik telah mencapai kedalaman 100 meter di Samudera Pasifik (Syafputri, 2014). Timbulan sampah yang terus bertambah juga dikarenakan oleh berubahnya pola konsumsi masyarakat, khususnya di perkotaan. Pola konsumsi di daerah perkotaan terlihat dari kebiasaan masyarakat membeli makanan dengan cara online, seperti makanan siap saji yang menggunakan wadah makanan sekali pakai, mulai dari tempat makan, sendok, garpu, dan pembungkusnya (BPS, 2018). 
Berdasarkan data tersebut dapat disimpulkan bahwa pertumbuhan penduduk yang tinggi dan pola konsumsi berdampak pada peningkatan penggunaan plastik sehingga berdampak pada timbulan sampah yang begitu besar. Berbagai upaya pengurangan sampah telah dilakukan oleh berbagai pihak seperti penerapan $4 \mathrm{R}$ yaitu dengan cara mengurangi (reduce), menggunakan kembali (reuse), mendaur ulang (recycle) dan mengganti dengan produk yang berulang kali pakai (replace). Hal ini dilakukan untuk menanggulangi permasalahan sampah plastik bagi lingkungan yang sampai saat ini belum ada solusi yang tepat untuk menyelesaikan permasalahan akibat semakin meningkatnya sampah plastik di lingkungan. Salah satu alternatif pemecahan masalah untuk mengurangi ketergantungan penggunaan sampah plastik yang sulit terurai adalah dengan membuat plastik ramah lingkungan yang dapat terurai dalam waktu yang cepat. Plastik biodegradable lebih ramah lingkungan karena berbahan dasar senyawa pati, protein, lignin, serta selulosa (Selpiana dkk, 2016).

$$
\text { Lopattananon dkk. }
$$

melakukan penelitian membuat plastik biodegradable yang berbahan baku dari pati tepung beras dan tepung tapioka tanpa penambahan bahan pemlastis. Hasilnya, plastik biodegradable yang berbahan baku dari tepung beras memiliki kuat tarik yang lebih besar daripada plastik biodegradable yang berbahan baku tepung tapioka. Namun plastik biodegradable yang berbahan baku dari tepung beras kurang fleksibel dibanding plastik biodegradable yang berbahan baku dari tepung tapioka. Maka dapat disimpulkan pula, bahwa kuat tarik plastik biodegradable yang berbahan baku dari tepung tapioka dan tepung beras akan meningkat kuat tariknya dengan cara meningkatkan komposisi tepung beras. Haryanto dkk (2016) membuat plastik biodegradable berbahan baku tepung tapioka dan tepung beras ketan putih dengan perbandingan komposisi tepung beras ketan putih dengan tepung tapioka sebesar 40:10, $30: 20,25: 25,20: 30$ dan 10:40. Plastik biodegradable yang dihasilkan memiliki serap air, tekstur permukaan, dan degradasi terbaik pada komposisi 20:30, sedangkan elongasi terbaik pada komposisi 40:10, dan kuat tarik terbaik pada komposisi 10:40.

Nasi aking merupakan limbah nasi yang sudah tidak layak untuk dikonsumsi oleh manusia karena telah basi, berbau, berjamur dan mengandung mikroorganisme yang merugikan kesehatan manusia. Nasi aking yang biasanya dibuang, sebagai limbah nasi aking dapat digunakan sebagai bahan baku pembuatan plastik biodegradable dengan menambahkan beberapa variasi bahan lain agar terbentuk plastik biodegradable dengan karakteristik sesuai yang diharapkan. Komposisi yang dimanfaatkan dari nasi aking sebagai bahan baku pembuatan plastik biodegradable adalah komposisi pati yang cukup tinggi untuk dapat dikombinasikan dengan bahan lainnya (Ramadhan dkk, 2019).

Penelitian mengenai pembuatan plastik biodegradable sebelumnya telah dilakukan oleh Selpiana dkk (2015) yang meneliti tentang pembuatan plastik biodegradable berbahan baku nasi aking yaitu membuat plastik biodegradable perbandingan komposisi kitosan sebanyak 3, 5, dan 7 gram dan komposisi gliserol sebanyak 0, 2, 4, 8, dan $10 \mathrm{~mL}$. Hasil penelitian tersebut adalah kuat tarik paling tinggi diperoleh pada komposisi kitosan dan gliserol sebanyak 7:2. Elongasi paling tinggi pada komposisi kitosan dan gliserol sebanyak 3:10. Persentase degradasi paling lambat terdapat pada plastik biodegradable dengan kadar kitosan 7 gr. Sedangkan Kumoro dkk (2014) membuat plastik biodegradable berbahan baku 
limbah tepung nasi aking dan tepung tapioka dengan penambahan variasi komposisi gliserol $0,10,15,20$, 30, 40 gram. Hasil penelitian menunjukkan bahwa kadar gliserol yang digunakan sebanyak $15 \%$ untuk membuat plastik biodegradable dari komposit tepung dengan rasio limbah tepung nasi aking: tepung tapioka 30: 70 dengan kuat tarik 20,65 $\mathrm{MPa}$, elongasi $4,7 \%$ dan modulus Young $1138 \mathrm{MPa}$. Martina dkk (2016) membuat plastik biodegradable berbahan baku nasi aking dengan variasi komposisi 3, 5, 7 gram dengan tambahan 3 gram kitosan dan $4 \mathrm{ml}$ gliserol. Kesimpulan yang didapat dari penelitian tersebut adalah semakin banyak komposisi kitosan yang ditambah dengan komposisi gliserol yang sama, maka hasil uji kuat tarik dan biodegradasi akan semakin meningkat.

Selain bahan baku, yang perlu diperhatikan dalam pembuatan plastik biodegradable adalah penambahan gliserol sebagai pemlastis dan kitosan sebagai penguat. Seperti pada penelitian sebelumnya yang dilakukan oleh Rahmawati (2018) yang meneliti variasi komposisi gliserol dan kitosan terhadap kualitas plastik biodegradable dari bekatul. Variasi komposisi yang diteliti yaitu gliserol 3,0; 4,5; 6,0 dan 7,5 $\mathrm{ml}$, sedangkan komposisi kitosan 2,0; 3,0 dan 4,0 gram. Hasil penelitian menunjukkan bahwa kondisi optimum sifat fisik plastik biodegradable dengan variasi komposisi kitosan dan gliserol sebanyak 3:6 menghasilkan uji kuat tarik sebesar 9,91 $\mathrm{MPa}$, persen elongasi $60 \%$, hasil uji ketahanan air $76 \%$ dan hasil uji biodegradabilitas $92 \%$.

Berdasarkan latar belakang di atas, maka perlu dilakukan penelitian optimalisasi komposisi gliserol dan kitosan terhadap hasil pengujian sifat fisik plastik biodegradable berbahan baku limbah nasi aking dan tepung tapioka. Pada penelitian ini dilakukan pembuatan plastik biodegradable dengan beberapa variasi komposisi kitosan dan gliserol. Penelitian ini dilakukan untuk mengetahui kondisi optimum komposisi gliserol dan kitosan terhadap hasil pengujian sifat fisik plastik biodegradable berbahan baku limbah nasi aking dan tepung tapioka.

\section{METODOLOGI}

\subsection{Alat dan Bahan yang digunakan}

Alat yang digunakan yaitu cetakan flexiglass, cawan petri, beaker glass 150 $\mathrm{ml}, 250 \mathrm{ml}$ dan $500 \mathrm{ml}$, gelas ukur $50 \mathrm{ml}$ dan $250 \mathrm{ml}$, termometer, pembakar bunsen, batang pengaduk/ spatula, pipet tetes, neraca analitik dan mesin kuat tarik. Bahan yang digunakan yaitu limbah nasi aking, tepung tapioka, gliserol, kitosan, aquades, asam asetat dan alkohol $96 \%$.

\subsection{Pembuatan Plastik Biodegradable}

10 gram tepung tapioka dan tepung nasi aking dibuat komposisi dengan perbandingan $3: 7$, lalu dilarutkan dengan $50 \mathrm{ml}$ larutan $\mathrm{CH}_{3} \mathrm{COOH} /$ asam asetat $2 \%$ dan diaduk 10 menit pada suhu $80^{\circ} \mathrm{C}$ dengan variasi komposisi kitosan sebanyak 3 gram, 5 gram, 7 gram dilarutkan dengan $100 \mathrm{ml} \mathrm{CH}_{3} \mathrm{COOH} 2 \%$ dan diaduk 25 menit pada suhu $80^{\circ} \mathrm{C}$ sampai larut. Selanjutnya larutan tepung nasi aking dan tepung tapioka dicampurkan kelarutan kitosan, lalu diaduk 15 menit kemudian ditambahkan variasi komposisi gliserol sebanyak 2, 4, $6,8 \mathrm{~mL}$ dalam larutan tepung nasi aking, tepung tapioka dan kitosan, lalu aduk selama 10 menit dengan temperatur $80^{\circ}$. Menuangkan larutan plastik ke dalam cetakan plastik yang sebelumnya telah dibersihkan dengan alkohol $96 \%$. Masukkan ke dalam oven pada suhu $75^{\circ} \mathrm{C}$ selama 4 jam, keluarkan cetakan dari oven dan didinginkan pada 
temperatur ruang selama 24 jam. Selanjutnya plastik biodegradable siap dianalisis (Martina, dkk, 2016).

\subsection{Pengujian Karakteristik Plastik Biodegradable}

\subsubsection{Kuat Tarik $(\sigma)$}

Sampel plastik biodegradable didiamkan pada ruang selama 24 jam pada kondisi suhu dan kelembaban standar $(23 \pm 20 \mathrm{C}, \quad 52 \%)$. Sampel plastik biodegradable dipotong berukuran $2 \times 8$ cm. Pengujian sampel plastik biodegradable dilakukan dengan cara menjepit kedua ujung sampel plastik. Kemudian catat panjang awal sebelum dan setelah penambahan beban. Kemudian lakukan pengujian lembar berikutnya (Selpiana dkk, 2016). Perhitungan kuat tarik disajikan pada persaman (1) sebagai berikut:

$\sigma=\frac{F m a k s}{A 0}$

Keterangan: $\mathrm{A}_{0}=$ luas penampang awal $\left(\mathrm{cm}^{2}\right)$; Fmaks $=$ beban maksimum $(\mathrm{kg})$

\subsubsection{Elongasi/elastisitas/regangan $(\varepsilon)$}

Pengukuran elongasi sampel plastik biodegradable menggunakan prosedur yang sama dengan uji kuat tarik. Perhitungan persen elongasi menggunakan persamaan (2) sebagai berikut (Selpiana dkk, 2015) :

$\varepsilon=\frac{\Delta \mathrm{l}}{10} \times 100 \%$

Keterangan: $l_{0}=$ panjang mulamula material yang diukur $(\mathrm{cm}) ; \quad \Delta 1$ $=$ pertambahan panjang $(\mathrm{cm})$;

\subsubsection{Uji Ketahanan Air}

Uji

plastik biodegradable

ketahanan air dengan cara memotong sample plastik biodegradable dengan ukuran $1 \times 1 \mathrm{~cm}^{2}$, lalu timbang berat awal sampel plastik biodegradable (Wo), lalu isi cawan petri dengan aquades. Kemudian sampel plastik biodegradable direndam dalam cawan petri selama 10 detik kemudian diangkat. Letakkan diatas tissu, kemudian sampel plastik biodegradable ditimbang sebagai data W. Selanjutnya sampel plastik biodegradable direndam kembali ke dalam cawan petri, lalu angkat plastik biodegradable setiap 10 detik, kemudian ditimbang. Lakukan hal ini hingga diperoleh berat akhir sampel plastik biodegradable yang konstan (Fahnur, 2017). Air yang diserap oleh sampel plastik biodegradable dihitung dengan persamaan (3) sebagai berikut:

Penyerapan $\operatorname{air}(\%)=\frac{\mathrm{W}-\mathrm{W} 0}{\mathrm{~W} 0} \times 100 \%(3)$

Keterangan : $\mathrm{W}_{0}=$ berat sampel kering; $\mathrm{W}=$ berat sampel setelah direndam air.

Kemudian persen air yang diserap sampel plastik biodegradable ditentukan menggunakan persamaan (4) sebagai berikut:

Ketahanan air $=100 \%-\%$ air diserap

\subsubsection{Uji Biodegradasi}

Sebelum sampel plastik biodegradable dikubur ke dalam tanah, potong sampel dengan ukuran $4 \mathrm{x} 1 \mathrm{~cm} 2$ lakukan penimbangan terlebih dahulu. Lalu setiap dua hari sekali sampel plastik biodegradable dikeluarkan dari dalam tanah untuk ditimbang kembali dalam keadaan kering (Fahnur, 2017). Biodegrabilitas dapat ditentukan melalui persamaan (5), (6) dan (7) untuk menentukan \% kehilangan berat, laju degradabilitas dan waktu degradasi sempurna sebagai berikut :

$\%$ Kehilangan Berat $=100 \%-\frac{(W 1-W 2)}{W 1} \times 100 \%$ 
Laju Degradabilitas $=\frac{(W 1-W 2)}{\text { Waktu Uji }}$

Waktu Degradasi Sempurna $=\frac{100 \%}{\% \text { kehilangan berat } x \text { Waktu } U j i}$ (7)

Keterangan: $\mathrm{W}_{1}=$ massa sampel pada hari ke-0 (mg); $\mathrm{W}_{2}=$ massa sampel pada hari ke- 2, 4, 6, 8, dan $10(\mathrm{mg})$.

\section{HASIL DAN PEMBAHASAN}

\subsection{Hasil Uji Kuat Tarik}

Hasil uji kuat tarik disajikan pada gambar 1 sebagai berikut:

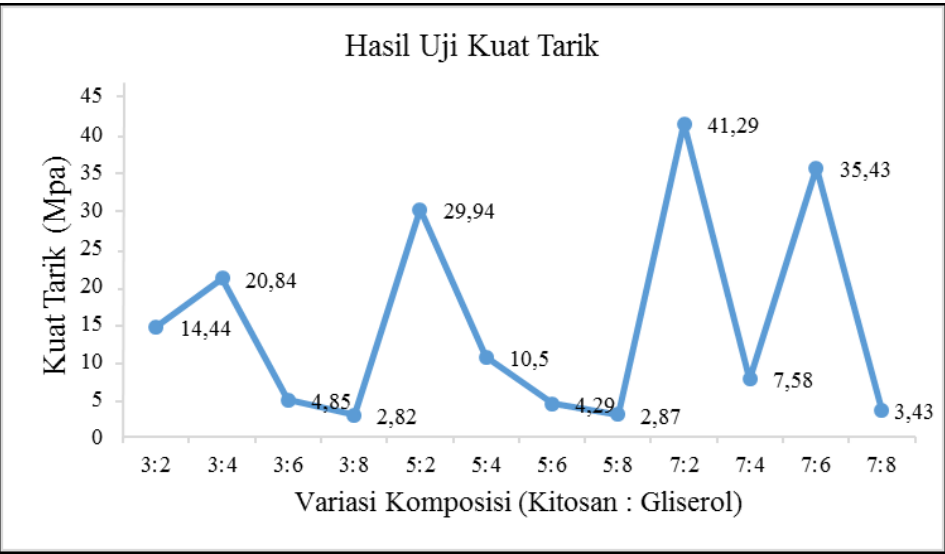

Gambar 1.

Grafik Variasi Komposisi Kitosan dan Gliserol terhadap Kuat Tarik

Hasil uji kuat tarik pada ikatan hidrogen yang terdapat di dalam penelitian ini menunjukkan bahwa film plastik biodegradable sehingga penambahan variasi komposisi ikatan antar-molekul dari plastik akan kitosan dan gliserol memiliki pengaruh semakin kuat. Hal ini membuktikan pada hasil uji kuat tarik. Nilai kuat tarik bahwa semakin banyak komposisi kitosan terbesar terdapat pada variasi dan semakin sedikit komposisi gliserol, komposisi kitosan 7 gr dan gliserol $2 \mathrm{ml}$ maka akan semakin besar pula nilai kuat yaitu 41,29 Mpa. Hal ini sesuai dengan tariknya sebagai akibat meningkatnya penelitian Selpiana dkk, 2015 yang ikatan hidrogen dari kitosan.

menunjukkan bahwa peningkatan

nilai kuat tarik terjadi karena peningkatan kadar kitosan yang semakin bertambah, sehingga menyebabkan

\subsection{Hasil Uji Persen Elongasi}

Hasil uji persen elongasi disajikan pada gambar 2 sebagai berikut: semakin banyaknya jumlah

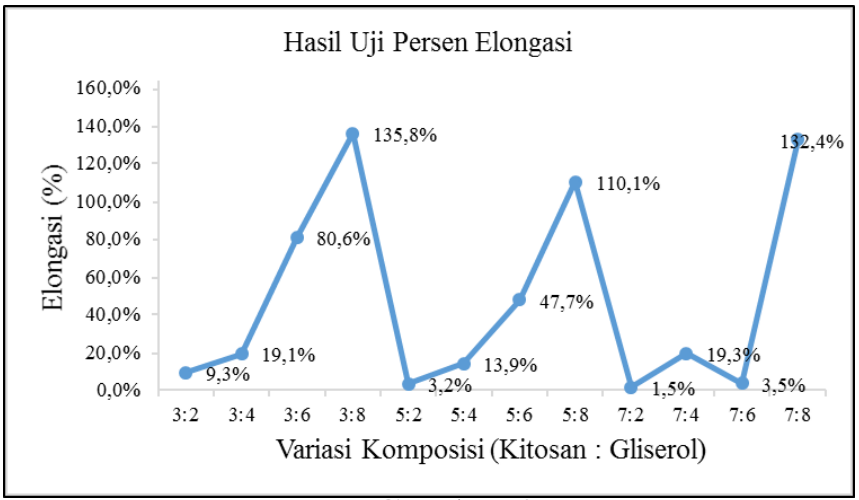

Gambar 2.

Grafik Variasi Komposisi Kitosan dan Gliserol terhadap Persen Elongasi 
Berdasarkan gambar di atas menunjukkan bahwa penambahan variasi komposisi kitosan dan gliserol memberikan variasi data pada hasil uji persen elongasinya. Pada variasi kitosan dengan rasio 3 menunjukkan bahwa keempat data pertama menunjukan peningkatan persen elongasi seiring dengan peningkatan rasio gliserol yang digunakan. Persen elongasi tertinggi terdapat ada variasi komposisi kitosan 3 gr dan gliserol $8 \mathrm{ml}$ yaitu $135,80 \%$. Hal ini sesuai dengan penelitian Kumoro dkk, (2014) yang menyatakan bahwa kadar gliserol yang semakin tinggi dalam campuran bahan pembuat plastik biodegradable akan meningkatkan persen elongasi plastik biodegradable yang dihasilkan. Hal ini menunjukkan bahwa semakin besar komposisi gliserol maka akan semakin besar pula persen elongasinya yang artinya plastic biodegradable dengan komposisi gliserol yang tinggi dapat mengalami pemanjangan/ bertambah kelenturannya dibandingkan dengan yang komposisi gliserolnya sedikit.

\subsection{Hasil Uji Ketahanan Air}

Hasil uji ketahanan air disajikan pada gambar 3 sebagai berikut:

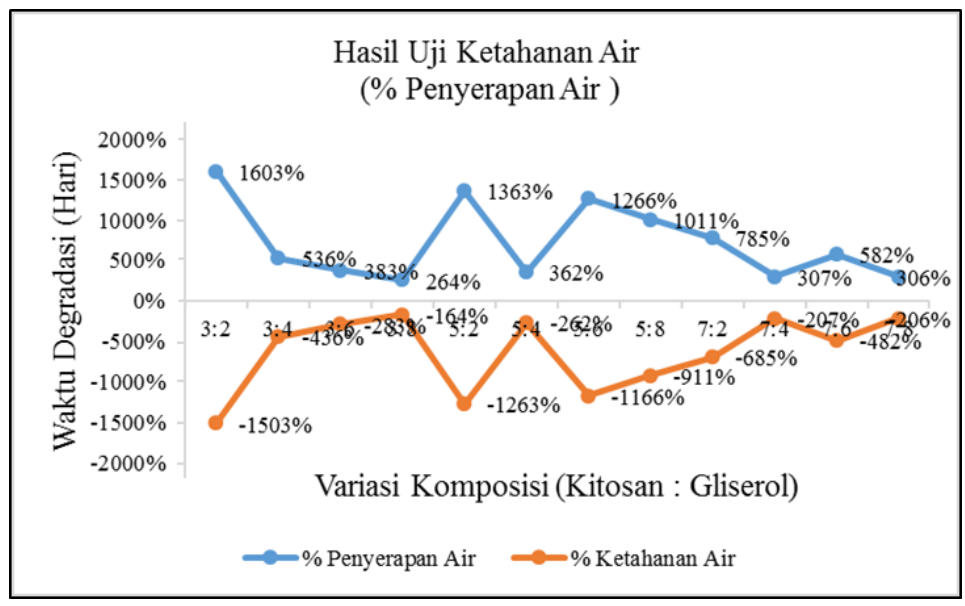

Gambar 3.

Grafik Variasi Komposisi Kitosan dan Gliserol terhadap Persen Ketahanan Air dan Penyerapan Air

Berdasarkan grafik di atas menunjukkan bahwa ketahanan air terendah terdapat pada variasi komposisi kitosan 3 gr dan gliserol $2 \mathrm{ml}$ yaitu sebesar $-1503 \%$, sedangkan ketahanan air tertinggi terdapat pada variasi komposisi kitosan 3 gr dan gliserol $8 \mathrm{ml}$ yaitu sebesar $-164 \%$. Hasil penelitian ini tidak sesuai dengan pernyataan Jabbar (2017) yang menyatakan bahwa persentase ketahanan air meningkat dikarenakan peningkatan komposisi kitosan dalam plastic biodegradable. Hal ini menunjukkan plastik biodegradable dari limbah nasi aking dan tepung tapioka tidak memiliki ketahanan air yang baik sehingga perlu dikembangkan penelitian lebih lanjut mengenai penambahan zat aditif lain yang dapat meningkatan ketahanan air. Garis warna biru pada grafik menunjukan presentase penyerapan air terendah terdapat pada variasi komposisi kitosan 3 gr dan gliserol $8 \mathrm{ml}$ yaitu sebesar 264\%, sedangkan penyerapan air tertinggi terdapat pada variasi komposisi kitosan 3 gr dan gliserol $2 \mathrm{ml}$ yaitu sebesar 
$1603 \%$. Hal ini tidak sesuai dengan hasil penelitian Intan dan Wan Aizan (2011) yang menyatakan bahwa persen penyerapan air oleh plastik biodegradable dari kulit singkong mengalami peningkatan akibat semakin banyaknya gliserol yang ditambahkan dalam campuran plastik biodegradable. Hal ini menunjukan bahwa penggunaan bahan baku juga sangat berpengaruh terhadap karakteristik plastik biodegradable yang dihasilkan, dalam hal ini sifat ketahanan air dan penyerapan airnya.

\subsection{Hasil Uji Biodegradasi}

Hasil uji biodegradasi plastik ditunjukkan oleh waktu biodegradasi sempurna dan laju biodegradasi plastik biodegradable yang disajikan pada gambar 4 dan 5 sebagai berikut:

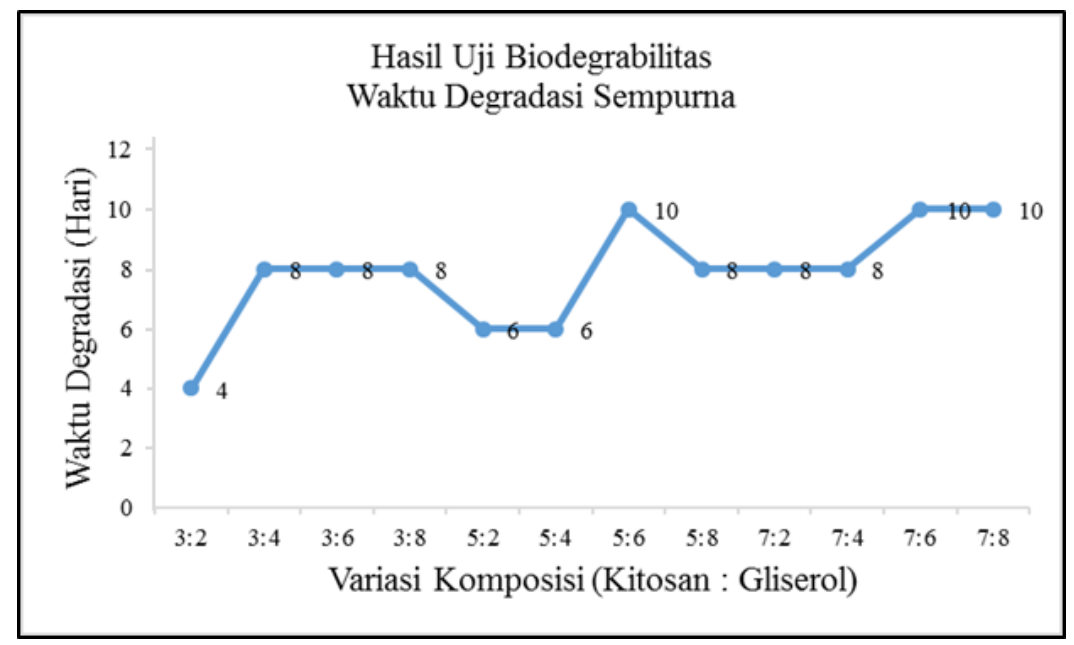

Gambar 4.

Grafik Variasi Komposisi Kitosan dan Gliserol terhadap Waktu Degradasi

Berdasarkan grafik di atas dapat terurai sempurna (Coniwanti, menunjukkan bahwa 2014). Rahmadani (2019) membuat plastik biodegradable dari limbah nasi plastic biodegradable dari pati ubi kayu aking dan tepung tapioka dapat dengan waktu degradasi selama 15 hari mengalami biodegradasi dalam waktu 4 untuk dapat terurai sempurna. Sedangkan sampai 10 hari tergantung dari variasi pada penelitian ini plastik biodegradable komposisi kitosan dan gliserolnya. Waktu dapat terdegradasi $100 \%$ pada hari ke 4 , degradasi plastic biodegradable menurut 6,8 dan 10. Hal ini menunjukkan nasi ASTM 5336 untuk plastik poli asam laktat aking dan tepung tapioka sangat mudah (PLA) dari Jepang dan poli- $\varepsilon^{-}$terdegradasi oleh tanah dalam waktu yang kaprolakton (PCL) dari Inggris cukup singkat. memerlukan waktu selama 60 hari untuk 


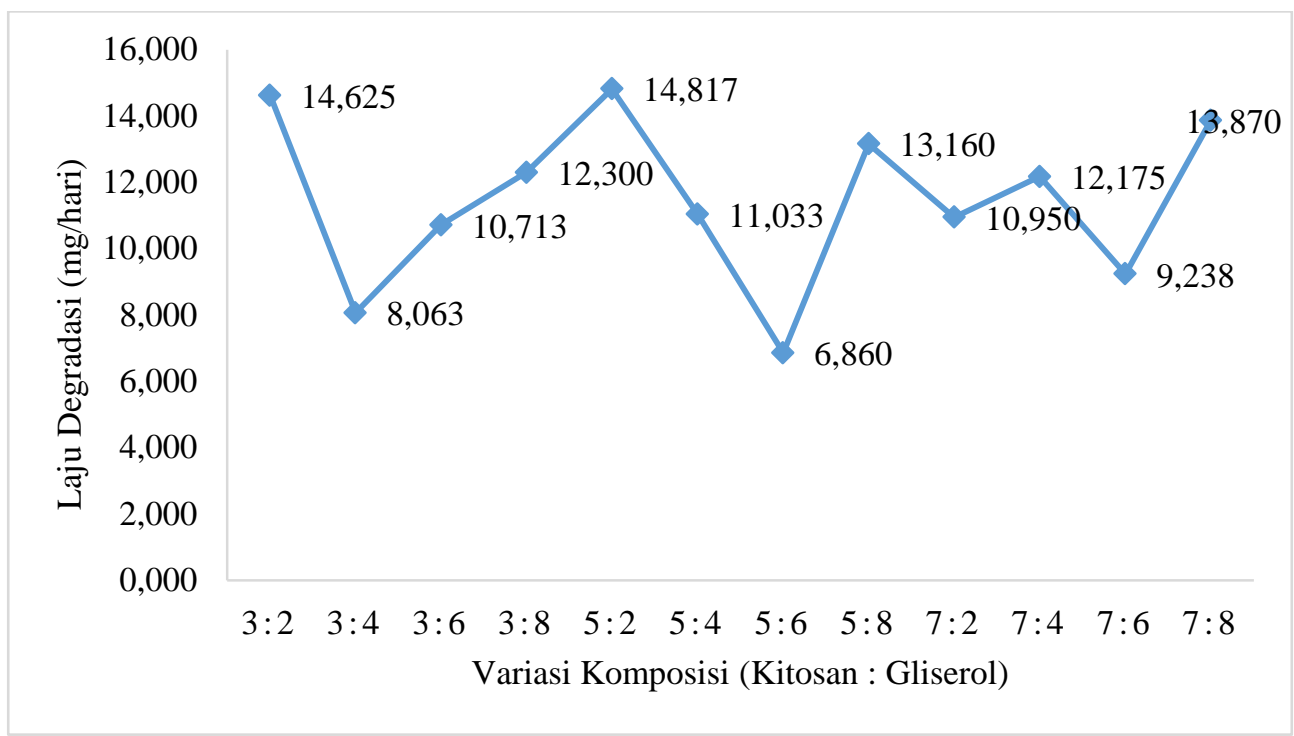

Gambar 5.

Grafik Variasi Komposisi Kitosan dan Gliserol terhadap Laju Degradasi

Berdasarkan gambar di atas menunjukkan bahwa laju degradasi plastic tertinggi pada variasi komposisi kitosan dan gliserol sebesar 5:2 diikuti oleh rasio 3:2 dengan data fluktuatif laju biodegradasi terendah pada komposisi 5:6. Menurut Hartatik dkk (2014), penambahan komposisi kitosan yang semakin meningkat maka akan menurun laju biodegradasinya, dan semakin banyak penggunaan pati serta komposisi gliserol yang digunakan, maka semakin meningkat laju biodegradasinya, hal ini karena pati dan gliserol bersifat hidrofilik. Data laju biodegradasi pada penelitian ini tidak sesuai dengan penelitian sebelumnya dikarenakan perbedaan bahan baku plastik biodegradable dan karena saat proses penimbangan banyak tanah yang menempel pada permukaan plastik biodegradable yang mulai terurai.

\section{SIMPULAN DAN SARAN}

\subsection{Simpulan}

Simpulan dalam penelitian ini adalah kondisi optimum komposisi gliserol dan kitosan yaitu pada komposisi kitosan gliserol sebesar 7:2 yaitu 41,29 $\mathrm{MPa}$, sedangkan untuk waktu biodegradasi optimum pada komposisi kitosan dan gliserol sebesar 3:2, untuk persen elongasi dan ketahanan air plastik biodegradable pada komposisi kitosan dan gliserol sebesar 3:8 yaitu sebesar $135,80 \%$ dan $-164 \%$.

\subsection{Saran}

Adapun saran yang diberikan untuk penelitian selanjutnya yaitu membuat variasi komposisi kitosan dan gliserol yang berbeda untuk mendapatkan kondisi optimum uji kuat tarik, persen elongasi, ketahanan air, dan degradasi yang terbaik dalam satu variasi serta pada waktu penimbangan plastik biodegradable diusahakan bersih dan tidak ada tanah yang menempel pada permukaan plastik yang mulai terdegradasi.

\section{DAFTAR PUSTAKA}

Badan Pusat Statistik. 2018. Statistik Lingkungan Hidup Indonesia 2018. Jakarta: Badan Pusat Statistik.

Coniwanti, Pamilia., Mertha., dan Eprianie, D. 2014. Pembuatan Film Plastik Biodegradable dari 
Pati Jagung dengan Penambahan Kitosan dan Pemlastis Gliserol. Jurnal Teknik Kimia. Universitas Sriwijaya.

Fahnur, Mardiana. 2017 Pembuatan, Uji Ketahanan dan Struktur Mikro Plastik Biodegradable dengan Variasi Kitosan dan Konsentrasi Pati Biji Nangka. Skripsi. Universitas Islam Negeri (UIN) Alauddin Makassar. Makassar.

Hartatik, D., Yunita, L.N.., dan Iswarin. 2014. Pengaruh Komposisi Kitosan terhadap Sifat Mekanik dan Biodegradable Plastik. Jurnal Jurusan Fisika FMIPA Universitas Brawijaya. Malang.

Haryanto, dan Saputri,A.E. 2016. Pengembangan Bioplastik dari Tapioka dan Tepung Beras Ketan Putih. Jurnal Skripsi. Perpustakaan Universitas Muhammadiyah Purwokerto. FT.

Intan, Dayangku H. dan Wan Aizan W.A.R. 02011. Tensile and Water Absorbtion of Biodegradable Composites Derived from Cassava Skin/Polyvinyl Alcohol with Glycerol as Plasticizer. Sains Malaysiana, 40(7):713-718.

Jabbar, Uhsnul Fatimah. 02017. Pengaruh Penambahan Kitosan terhadap Karakteristik Bioplastik dari Pati Kulit Kentang (Solanum Tuberosum. L). Universitas Islam0Negeri (UIN) Alauddin Makassar. 0Makassar.

Kumoro, Andri Cahyo., dan Purbasari.A., 2014. Sifat Mekanik dan Morfologi Plastik Biodegradable dari Limbah Tepung Nasi Aking dan Tepung Tapioka Menggunakan Gliserol Sebagai Pemlastis. Jurnal Skripsi. Perpustakaan Universitas Diponegoro. Fakultas Teknik.

Lopattananon, N., Thongpin, C. dan Sombabsompop, N. 2012. Bioplastik from Blend of Cassava and Rice Flours: The Effect of
Blend Composition.International Poly mer Processing, XXVII, 3 , 334-340.

Martina, Sufiya Putri, Masturi., dan Ian Yulianti. 2016. Analisis Plastik Biodegradable Berbahan Dasar Nasi Aking. Jurnal Ilmu Pendidikan Fisika. Universitas Negeri Semarang. Semarang.

Rahmadani, Sry. 2019. Pemanfaatan Pati Batang Ubi Kayu dan Pati Ubi Kayu untuk Bahan Baku Alternatif Pembuatan Plastik Biodegradable. Jurnal Teknologi Kimia Unimal. Kampus Bukit Indah Lhokseumawe.

Rahmawati, Arista Dwi. 2018. Pengaruh Variasi Komposisi Gliserol dan Kitosan Terhadap Kualitas Plastik Biodegradable dari Bekatul. Universitas Muhammadiyah Surakarta. Surakarta.

Ramadhan, Mochamad Bryan., Fika Oktavia., dan Febriyanti. 2019. INSTING (Inovasi Plastik Dari Tepung Nasi Aking) dengan Penguat Alami Kitosan dan Asam Oleat. Jurnal Teknik Kimia. Universitas Muhammadiyah Purwokerto. Purwokerto.

Syafputri, E. 2014. Produksi Sampah Plastik Indonesia 5,4 Juta Ton per Tahun. http://www.antaranews.com/ berita/417287/produksi-sampahplastik-indonesia-54- juta-ton-pertahun. 0Diakses 15 desember 2019.

Selpiana, Riansya, J.F., Yordan, Kevin. 2015. Pembuatan Plastik Biodegradable dari Tepung Nasi Aking. Jurnal Teknik Kimia. Universitas Sriwijaya.

Selpiana, Patricia., C.P. Anggraeni. 2016. Pengaruh Penambahan Kitosan dan Gliserol pada Pembuatan Bioplastik dari Ampas Tebu dan Ampas Tahu. Jurnal Skripsi. Perpustakaan Universitas Sriwijaya. FT. 